\title{
Correction to: Adipose tissue-derived stem cells: a comparative review on isolation, culture, and differentiation methods
}

\author{
Saber Khazaei $(\mathbb{D} \cdot$ Ghazal Keshavarz $(\mathbb{D})$ Azam Bozorgi $(\mathbb{D} \cdot$ Hamed Nazari • \\ Mozafar Khazaei $($ D)
}

Published online: 13 May 2021

(C) Springer Nature B.V. 2021

\section{Correction to: Cell Tissue Bank https://doi.org/10.1007/s10561-021-09905-z}

In the original publication of this article the affiliation of the co-author Dr Azam Bozorgi was mistakenly published and the same has been corrected.

The original article can be found online at https:// doi.org/10.1007/s10561-021-09905-z.

\section{S. Khazaei}

Department of Endodontics, School of Dentistry, Kermanshah University of Medical Sciences, Kermanshah, Iran

e-mail: saber.khazaei@yahoo.com

G. Keshavarz · A. Bozorgi · M. Khazaei ( $\square)$

Fertility and Infertility Research Center, Health

Technology Institute, Kermanshah University of Medical

Sciences, Kermanshah, Iran

e-mail: mkhazaei1345@yahoo.com

G. Keshavarz

e-mail: ghazalkeshavarz1224@gmail.com

A. Bozorgi

e-mail: abozorgi1991@gmail.com

\section{A. Bozorgi}

Department of Tissue Engineering and Regenerative Medicine, School of Advanced Technologies in Medicine, Iran University of Medical Sciences, Tehran, Iran
Publisher's Note Springer Nature remains neutral with regard to jurisdictional claims in published maps and institutional affiliations.

H. Nazari

Department of Orofacial Surgery, School of Dentistry,

Kermanshah University of Medical Sciences,

Kermanshah, Iran

e-mail: nazari.hamed67@yahoo.com 